\title{
The Influence of Social Capital in Economic Development in Indonesia: Macro Data Analysis of 2012 and 2014
}

\author{
${ }^{1}$ Fahmi Tanjung and ${ }^{2}$ Muryani ${ }^{*}$ \\ ${ }^{1}$ Department of Economics and Business \\ ${ }^{2}$ Department of Economics \\ Airlangga University \\ Surabaya, East Java \\ Indonesia
}

\begin{abstract}
The new paradigm development is not only measured from the economic aspect through Gross Domestic Product (GDP), but also viewed multidimensionally from the change of social structure, behavior, and national institution. Such social perspective is called social capital. Social capital is considered an important determinant of economic development. So that social capital is placed as one input in development. The purpose of this scientific paper is to analyze the influence of social capital in the economic development of the approach of Gross Regional Domestic Product (GRDP) in 33 Provinces in Indonesia. The analysis of the effect of social capital on GRDP along with other variables such as physical capital, labor, and human capital is done at the macro level. The limits are the role of social capital in 2012 and 2014 due to data availability. The result of research indicates that social capital has not been enough to influence human capital at the macro level, while human capital has a significant effect on the Gross Regional Domestic Product (GRDP). It can say that social capital indirectly is no longer effected on GRDP in Indonesia.
\end{abstract}

Keywords: Social Capital, Gross Regional Domestic Product, Instrumental Variable.

\section{INTRODUCTION}

So far, the benchmark of national development success tends to be seen from the economic aspect, where the measure of its success is measured by Gross Domestic Product (GDP). Political, social, demographic, and cultural aspects allegedly contributed to the process. A new paradigm in development is looked at it multidimentially from changes in social structure, behavior, and national institutions (Sugianto, 2010). The changes are reflected in various social perspectives such as mutual trust and tolerance, participation in groups, and networks within society. Such social perspective is called social capital. In harmony with this, the Organization for Economic Co-operation and Development (OECD), the economic cooperation organization, places social capital as one of the inputs in development.

Romer (1986) in the new development theory reveals that the output of GDP is influenced by physical capital, labor, and human capital. This means that the role of social capital is not being included in the theory. Christoforou (2003) reveals that social capital encourages economic growth by emphasizing the importance of cooperation and trust within institutions, enterprises, and countries as well as between individuals. The concept of social capital is also considered an important determinant in economic development (Khaldaru and Part, 2005). The emphasis on the concept of social capital on elements of macro level consisting of institutional relationships between individuals and institutional structures and their functions in society. Neira (2008) reveals the role of social capital as well as human capital or labor can be an investment in the future, but social capital cannot make economic growth itself. 
The purpose of this scientific paper is to analyze the influence of social capital in economic development of the approach of Gross Regional Domestic Product (PDRB) in 33 Provinces in Indonesia. The analysis of the effect of social capital on PDRB along with other variables such as physical capital, labor, and human capital is done at the macro level. The limits taken are the role of social capital in 2012 and 2014 due to data availability.

The structure in this first scientific paper discusses the concept of economic development with social capital and its linkage analysis. The second section deals with the results of empirical studies and literature studies on social capital relations and economic development. The third section deals with empirical studies with methodologies and macro-level statistics in Indonesia. The final section discusses the results of empirical studies along with an analysis of the findings.

\section{LITERATURE SURVEY}

The relationships between social capital and economic development are complex, partly because of the ambiguity and complexity of the initial concept. There are various approaches to defining, measuring, and applying the concept of social capital. In general social capital includes networks along with shared norms, values and understandings that facilitate cooperation within or between groups (OECD 2001: 41). The formation of social capital and its effects can analyze at different levels, i.e at the micro level (individual trust and informal relationships between individuals), at the meso level (community), and at the macro level (regional, national, international and institutional networks).

Social capital at the macro level is a step in which social capital is exploited over a wider range. At this stage the use of social capital includes, like the government, the enforcement of civil law certainty, political freedom, impact on the economic achievement of a country, the determination of a government function, and the type of public sector economic development. In relation to the public sector, government involvement that builds development under the imbalance between external social capital ties, and internal cohesion is essential. Social capital at the macro level refers to governmental institutions that affect people's ability to work together for mutual benefit (Knack, 1999). Government social capital embodies the rule of law, contract enforcement, absence of corruption, transparency in decision making, efficient administrative systems, reliable legal systems - in short, state capability and credibility (Meier, 2002). There is a positive and significant relationship between social capital at the macro level and economic growth (Kaldaru, 2005).

The relationships between human capital and social capital are mainly emphasized on the influence of social capital in accumulating human capital. Human capital is influenced mainly by civil social capital (Parts, 2003). Parts (2013) conducted a study of 45 countries in Europe. The results of this study indicate that the most influential factor on social capital is education and satisfaction with democracy.

\section{RESULT}

Endogenic occurs when the explanatory variable correlates with the error so that the OLS estimation becomes inconsistent. One way to overcome the problem of endogenity is the use of Instrument Method Variable (IV). Method IV uses the least squares estimation of two-stage regression method or two-stage least square regression (2SLS Regression). When explanatory variables correlate or show some form of dependence, the instrumental variables can provide consistent estimates. A variable $\mathrm{z}$ is called the instrumental variable for the model $\mathrm{y}=\beta \mathrm{x}+\mathrm{u}$ if it is not correlated with the error $\mathrm{u}$ but correlates with the explanatory variable $\mathrm{X}$.

The model used in this study refers to the Romer (1986) model that incorporates the human capital variable as the output formatter, in addition to the "traditional" input of capital and labor.

$$
Y=f(K, L, H)
$$

Where

$\mathrm{Y}=$ output

$\mathrm{K}=$ Capital

$\mathrm{L}=$ Labor

H= Human Capital

In this study, the model is specified as:

$$
\begin{aligned}
& \text { Output }_{i t}=\alpha_{1} \text { DomesticInvesment }_{i t}+\alpha_{2} \text { ForeignInvesment }_{i t}+\alpha_{3} \text { CapitalExpenditure }_{i t}+\alpha_{4} \text { Labor }_{i t} \\
& \quad+\alpha_{5} \text { HumanCapital }_{i t}
\end{aligned}
$$


From the theory of human capital, human capital refers to the stock of knowledge, habits, social attributes and personality, including creativity, which is manifested in the ability to do work to produce economic value so that in this study is specified as:

$$
\begin{aligned}
\text { HumanCapital }_{i t} & =\beta_{0}+\beta_{1} \text { EducationSpending }_{i t}+\beta_{2} \text { Qualification }_{i t}+\beta_{3} \text { Puskesmas }_{i t}+\beta_{4} \text { GeneralPractitioners }_{i t} \\
& +\beta_{5} \text { Dentist }_{i t}+\text { SocialCapital }_{i t}
\end{aligned}
$$

From the introduction, social capital is defined as:

ModalSosial $_{i t}=\gamma_{0}+\gamma_{1}$ Politic $_{i t}+e_{t}$

Where

i: province, with $\mathrm{i}=1,2,3,4,5, \ldots \ldots \ldots \ldots 33$

$\mathrm{j}$ : year of observation, with $\mathrm{t}=2012,2014$

\begin{tabular}{|c|c|}
\hline Variable & Definitions and Measurements \\
\hline Output & : Natural logarithm of GDP values constant value \\
\hline $\begin{array}{l}\text { Domestic } \\
\text { Investment }\end{array}$ & : Natural logarithm of investment value of PMDN \\
\hline $\begin{array}{l}\text { Foreign } \\
\text { Investment }\end{array}$ & : Natural logarithm of investment value of PMA \\
\hline $\begin{array}{l}\text { Capital } \\
\text { Expenditure }\end{array}$ & : Logarithm natural value of government spending for capital expenditure \\
\hline Labor & : Logarithmic natural population of 15 years and over who worked \\
\hline Human Capital & : Human Development Index \\
\hline $\begin{array}{l}\text { Education } \\
\text { Spending }\end{array}$ & : Logarithm natural value of government spending for education \\
\hline Qualification & $\begin{array}{l}\text { Percentage of population with the highest education at least senior high } \\
\text { school }\end{array}$ \\
\hline Puskesmas & $\begin{array}{l}\text { Ratio of government-mandated community health clinics located across } \\
\text { Indonesia. }\end{array}$ \\
\hline $\begin{array}{l}\text { General } \\
\text { practitioners }\end{array}$ & : GP ratio per population \\
\hline Dentist & : Dental ratio per population \\
\hline Social Capital & : Social Capital Index \\
\hline Political & $\begin{array}{l}\text { Aspects of political rights of the components of the Indonesia Democracy } \\
\text { Index }\end{array}$ \\
\hline
\end{tabular}

Table 1. Definition and Measurement of research variables

In this study, the endogenous test results showed the test on the human capital variable found that the $\mathrm{p}$ value is 0.0025 , which are smaller than $\alpha=5 \%$. The Null hypothesis H0 is rejected, meaning there is endogeneity. From this result, it can say that human capital variable is endogenous variable. The same is done for equation (3), obtained p-value of 0.0572 , which is smaller than $\alpha=10 \%$. In the same way, it can say that social capital variable is an endogenous variable. From this, it can conclude that there is an endogenous problem in the model so that the appropriate analysis for model parameter estimation uses Regression 2 SLS. Model estimation results are shown in Table 2. 
International Journal of Advances in Scientific Research and Engineering (ijasre), Vol 5 (3), March-2019

Table 2. Estimation of Model Parameters and Significance

\begin{tabular}{|c|c|c|c|c|}
\hline \multicolumn{2}{|c|}{ Variable } & \multirow{2}{*}{$\frac{\text { Test Statistic }}{-0.008}$} & \multirow{2}{*}{$\frac{\text { Error }}{0.028}$} & \multirow{2}{*}{$\frac{\text { Significant }}{\text { not significant }}$} \\
\hline Output & PMDN & & & \\
\hline & PMA & 0.012 & 0.010 & not significant \\
\hline & Capital Expenditure & $0.743^{* *}$ & 0.082 & Significant \\
\hline & Labor & $0.509^{* *}$ & 0.051 & Significant \\
\hline & Human Capital & $0.086^{* *}$ & 0.013 & Significant \\
\hline & Constant & $-7.536^{* *}$ & 1.016 & Significant \\
\hline Statistic F & & $227.29^{* *}$ & & Significant \\
\hline \multirow[t]{7}{*}{ Human Capital } & Education Spending & $2.104^{*}$ & 1.070 & Significant \\
\hline & Qualification & $0.362^{* *}$ & 0.038 & Significant \\
\hline & Puskesmas & $-0.574^{* *}$ & 0.134 & Significant \\
\hline & General Practitioner & 0.055 & 0.082 & not significant \\
\hline & Dentist & 0.103 & 0.218 & not significant \\
\hline & Social Capital & 0.043 & 0.075 & Not sigficant \\
\hline & Constant & $66.469^{* *}$ & 7.258 & Significant \\
\hline Statistic F & & $42.55^{* *}$ & & \\
\hline \multirow[t]{2}{*}{ Social Capital } & Political & $0.277^{* *}$ & 0.041 & Significant \\
\hline & Constant & $32.665^{* *}$ & 3.167 & Significant \\
\hline Statistic F & & $46.59^{* *}$ & & Significant \\
\hline
\end{tabular}

* Significance at the level of confidence $10 \%$

** Significance at the level of confidence $5 \%$

Table 2. shows the Estimation of Model Parameters and Significance factors. Tthe test of model parameters, show that the test of $\mathrm{F}$ for equation (1) with the p-value $=0.000$ meaning significant which means the together explanatory variable in equation (1) that is PMDN investment, foreign investment, government capital expenditure, labor and human capital, able to explain the variation of output. Similarly, equation (2), education expenditure variable, percentage of population with high school education and above, the ratio of puskesmas, the ratio of general practitioner, dentist, and social capital together can explain the diversity of human capital. Similarly to equation (3), the political rights aspect variable can explain the variation of social capital.

From the significance test, political rights significantly affect social capital, where each addition of political rights, will increase social capital by 0.28 points of social capital with the assumption that other variables are considered constant. Participation in political activities in Indonesia that is still relatively high such as participation in the election of head of state or regional head and express his political opinion by acting as sympathizers or cadres of certain political parties is a form of belief that the political process capable of channeling individual opinions in determining the direction of life of the state. The presence of a democratic culture means that no group dominates over other groups. The willingness to engage in political activities shows that active interpersonal relationships include trust, mutually beneficial cooperation, shared values and behaviors that bind every member of the network and the community as well as the possibility of making cooperation.

\section{DISCUSSION}

Meanwhile, social capital is not sufficient enough to affect human capital. This means that the macro level of social capital index formation has not been able to be measured properly as one of the factors that form human capital. Social capital in some aspects is objective, but others are subjective. The size of social capital is also cognitive. On the other hand, human capital, measured using the HDI approach, measures educational outcomes, health outcomes and welfare outcomes.

Conventional human capital is something that is gained from education both at university and other levels of education, training and so on, that are related to capacity building. While social capital is a capability born from the trust of the general public 
or small groups, to support the process of life both economic and non-economic. It is therefore, necessary to measure a more appropriate approach to measure the relationship between the two. It is possible that micro-scale social capital approach can better describe the correlation between the two. Apart from these two conclusions, equation (1) shows that in addition to capital and labor inputs, human capital has also been shown to have a positive effect on output. It can interpret that every addition of 1 point of human capital will increase output by 2.1 percent, assuming other variables are considered constant.

\section{CONCLUSION}

The results of the three models using 2 SLS, equation (3) showed that the rights of politics significantly affect social capital. Meanwhile, equation (2) suggests that social capital is not sufficiently capable of affecting human capital. This means that the macro-level of formation of social capital index has not been able to be measured properly as one of the factors that make up human capital. Apart from these two conclusions, equation (1) shows that in addition to capital and labor inputs, human capital has also been shown to have a positive effect on output of GRDP. It can say that social capital indirectly, does not affect the GRDP in Indonesia.

\section{REFERENCES}

1. A.C. Cameron \& P. Trivedi, Microeconometrics: Methods \&Applications.Cambridge: Cambridge University Press, 2005.

2. A. Christoforou, On the Identity of Social Capital and The Social Capital of Identity. Cambridge Journal of Economics 37, 719$736,2003$.

3. J. Jumirah, \& H. Wahyuni, The Effect of Social Capital on Welfare in Indonesia. Journal of Indonesian Economy and Business, 33(1), 65-76, 2018.

4. H.Khaldaru and Eve, The effect of Macro-Level Social Capital on Sustainable Economic Development. Tartu: Tartu University Pers, 2005.

5. S.Knack, Social Capital, Growth and Poverty: A Survey of Gross-Country Evidence.The World Bank Social Capital Initiative Working Paper, No 7, 2005.

6. Meier, G. M, Culture, Social Capital, and Management in a Developing Economy.Zagreb International Review of Economics \& Business. Vol. 5, No. 1, pp. 1-15, 2002.

7. Neira et al, An empirical Analysis of Social Capital and Economic Growth in Europe (1980-2000). Springer Science, 2008.

8. OECD, The Well-Being of Nations, the Role of Human and Social Capital. Paris: OECD, 2011.

9. Parts, Inter-relationship Between Human Capital And Social Capital: Implication For Economic Development In Transition Economies. Tartu: Tartu University Pers, 2003.

10. P. Romer, Increasing Returns and Long Run Growth. Journal of Political Economy, 94, 1002-37, 1986.

11. Sugiyanto Catur, AnalisisIndikatorEkonomi, Yogyakarta: PSEKP UGM 